\title{
Evidence for reduced biogenic silica dissolution rates in diatom aggregates
}

\author{
B. Moriceau ${ }^{1,2, *}$, M. Garvey ${ }^{1}$, O. Ragueneau ${ }^{2}$, U. Passow ${ }^{1}$ \\ ${ }^{1}$ Biogeoscience, Alfred Wegener Institut, am Handelshafen 12, 27570 Bremerhaven, Germany \\ ${ }^{2}$ UMR 6539, IUEM, Technopôle Brest-Iroise, 29280 Plouzané, France
}

\begin{abstract}
Because aggregated diatoms sink rapidly through the water column, leaving little time for dissolution, aggregation influences the balance between recycling of biogenic silica $\left(\mathrm{bSiO}_{2}\right)$ and its sedimentation and preservation at the seafloor. Additionally, aggregation may directly impact dissolution rates of opal. Laboratory experiments were conducted to investigate the influence of aggregation on $\mathrm{bSiO}_{2}$ dissolution rates using 3 different batch cultures of the diatoms Chaetoceros decipiens, Skeletonema costatum, and Thalassiosira weissflogii. Specific dissolution rates of $\mathrm{bSiO}_{2}$ of aggregated and freely suspended diatoms were compared. Additionally, the influences of the dissolved silicon $(\mathrm{dSi})$ concentration in the pore water of aggregates, the viability of diatoms, and the concentrations of transparent exopolymer particles (TEP) and of bacteria on $\mathrm{bSiO}_{2}$ dissolution rates were determined. Initial specific dissolution rates of diatom frustules were significantly lower for aggregated diatoms $\left(2.9 \% \mathrm{~d}^{-1}\right)$ than for freely suspended diatoms $\left(6.6 \% \mathrm{~d}^{-1}\right)$. Lower specific dissolution rates in aggregates were attributed to elevated dSi concentrations in aggregate pore water (maximum 230 vs. $20 \mu \mathrm{mol} \mathrm{l}^{-1}$ ) and to the fact that aggregated diatoms remained viable for longer than freely suspended diatoms. Specific $\mathrm{bSiO}_{2}$ dissolution was significantly correlated to viability of cells independent of treatment. Bacterial concentrations in both treatments appeared high enough, so that after cell death the coating protecting the silica frustule was degraded without measurable delay. The TEP content of aggregates appeared to affect dissolution rates, possibly by retaining solutes within aggregates.
\end{abstract}

KEY WORDS: Diatom aggregate - Biogenic silica dissolution - Silica recycling - Marine snow · Viability $\cdot$ Aggregate pore water

\section{INTRODUCTION}

In many areas of the ocean, diatoms are the most important primary producers; they commonly form the basis of productive food webs (Silver et al. 1978, Cushing 1989, Thornton 2002), and they are responsible for a large fraction of the vertical export of carbon (e.g. Goldmann 1993, Ragueneau et al. 2001). Diatoms require dissolved silicon $(\mathrm{dSi})$ to form their frustules. Intense recycling of this biogenic silica $\left(\mathrm{bSiO}_{2}\right)$ occurs within the mixed layer, with approximately $50 \%$ of the biogenic silica produced in the euphotic zone dissolving in the upper $100 \mathrm{~m}$ of the water column (Nelson et al. 1995, Ragueneau et al. 2000, 2002). Diatoms excrete dissolved polysaccharides that abiotically form trans- parent exopolymer particles (TEP) (Passow 2000) and enable the formation of these large aggregates (Passow et al. 1994, Passow \& Alldredge 1995a). A large fraction of a diatom bloom may thus aggregate into marine snow and be rapidly transported to depth (Graf 1992, Smith et al. 1996, Thornton 2002), as aggregation increases the sinking velocity of diatoms by 2 orders of magnitude (50 to $100 \mathrm{~m} \mathrm{~d}^{-1}$; Alldredge \& Gotschalk 1988, Alldredge \& Silver 1988).

Grazing by zooplankton and the production of silicarich fecal pellets with a sinking velocity 30 -fold greater than that of single cells (12 to $77 \mathrm{~m} \mathrm{~d}^{-1}$; Wassmann et al. 1999, Turner 2002) also result in the rapid transport of diatoms to depth. This transport of diatoms to depth shifts the dissolution of $\mathrm{bSiO}_{2}$ to below the euphotic 
zone, strengthening the silica pump described by Dugdale et al. (1995). The newly recycled dSi must be transported back to the euphotic zone before it can support additional diatom production.

Very little is known about the processes of the silica cycle that occur below the euphotic zone. Our goal within the European Program ORFOIS (ORigin and Fate of biogenic particle fluxes in the Ocean and their Interactions with the atmospheric $\mathrm{CO}_{2}$ concentration as well as the marine Sediment) has been to improve parameterization of the siliceous component of the particle fluxes through the water column. In particular, we have been interested in quantifying the dissolution rates of biogenic silica contained within sinking aggregates, as these particles are a major component of the downward flux (Thornton 2002, Turner 2002).

Rates of $\mathrm{bSiO}_{2}$ dissolution depend on biological variables, including bacterial number and activity (Patrick \& Holding 1985, Bidle \& Azam 1999, 2001), on chemical variables like dSi concentrations (Van Cappellen \& Qiu 1997a,b) and on physical variables like temperature (Kamatani 1982, Bidle et al. 2002). Consideration of $\mathrm{bSiO}_{2}$ dissolution as it occurs below the euphotic zone needs to take into account that sinking diatom frustules at these depths are mostly contained within aggregates or fecal pellets. This encapsulation could result in enhanced rates of dissolution due to the elevated rates of microbial activities on aggregates (Smith et al. 1992). Alternatively, dissolution rates could be diminished by high concentrations of silicic acid in the pore space of the aggregates (Brzezinski et al. 1997).

Schultes et al. (unpubl.) and Gallinari et al. (unpubl.) measured $\mathrm{bSiO}_{2}$ dissolution of diatom frustules embedded in copepod fecal pellets. These experiments indicated that dissolution rates of diatom cells were reduced if cells were enclosed in intact fecal pellets. The first laboratory measurements of $\mathrm{bSiO}_{2}$ dissolution rates of aggregated versus non-aggregated diatoms also indicated that incorporation within aggregates decreased $\mathrm{bSiO}_{2}$ dissolution rates, but the trends were somewhat ambiguous, as the continuous release of diatoms from and reincorporation into aggregates obscured the results (Passow et al. 2003). Here, we present unequivocal results of laboratory measurements of $\mathrm{bSiO}_{2}$ dissolution of aggregated versus non-aggregated cells under otherwise identical conditions. Furthermore, we address the role of TEP concentration, bacterial abundance and dSi concentration in the pore water of aggregates, as well as the viability of diatoms for $\mathrm{bSiO}_{2}$ dissolution rates.

\section{MATERIALS AND METHODS}

$\mathrm{bSiO}_{2}$ dissolution rates of aggregated and nonaggregated diatoms were compared in 8 experiments with a total of 18 treatments conducted with Skeletonema costatum (North Sea 1997), Chaetoceros decipiens (CCMP173), and Thalassiosira weissflogii (CCMP1053). These 3 diatom species were chosen because of their abundance in natural marine snow and their abilities to grow and to aggregate in culture. S. costatum and $C$. decipiens form chains, whereas $T$. weissflogii does not. Five treatments were conducted with freely suspended cells, and 13 treatments were conducted with aggregated cells. A greater number of treatments with aggregates were conducted, because of the high variability of replicate aggregates.

Diatoms used in the same experiment were derived from the same batch culture to ensure that they were physiologically as identical as possible. Although all batch cultures were grown under identical conditions and used for experiments in stationary phase, diatoms from different experiments differed in their physiological conditions, as evidenced for example by differences in the viability or TEP concentrations (see below). It is challenging to generate both an aggregated and a freely suspended treatment from cells of the same batch culture, because when cells are in aggregation mode, they tend to aggregate under almost any circumstances. We were not able to keep diatoms freely suspended in Expts 1, 2, and 7; and only aggregate treatments exist from these experiments (see Table 2).

Preparation of experiments. Batch cultures of the respective diatoms were grown in $f / 2$ media made from natural seawater (Guillard \& Ryther 1962, Guillard 1975), at $13^{\circ} \mathrm{C}$, with an irradiance of $100 \mu \mathrm{mol} \mathrm{m} \mathrm{m}^{-2}$ $\mathrm{s}^{-1}$ in a 12:12 h light:dark cycle. Except during the growth period, no glassware was used during the experiment. When a high cell concentration was reached $\left(2 \times 10^{5}\right.$ to $4 \times 10^{5}$ cells $\left.\mathrm{ml}^{-1}\right)$, at or near stationary phase (Fig. 1, Step 1), a part of the batch culture was incubated in a 41 cylindrical acrylic tank made with non-toxic glue. The diatoms were kept on a roller table in the dark at $13^{\circ} \mathrm{C}$ to promote the formation of aggregates (Shanks \& Edmondson 1989). Speeds of roller tables (about $0.5 \mathrm{rpm}$ ) were such that aggregates sank continuously, without spending time lying at the bottom of the roller table. The second aliquot of the batch culture was incubated in a 11 polycarbonate flask, under the same environmental conditions as the aggregate treatment, except that the flask was placed on a shaker table (Fig. 1, Step 1), where gentle, horizontal agitation kept cells in suspension without visible aggregation. The diatoms in both treatments (aggregated and freely suspended cells) were incubated for $2 \mathrm{~d}$ to 1 wk until >100 large aggregates of approximately the same size had formed in the aggregate treatment. At this time the size of aggregates also stopped increasing. The final aggregate mean size var- 


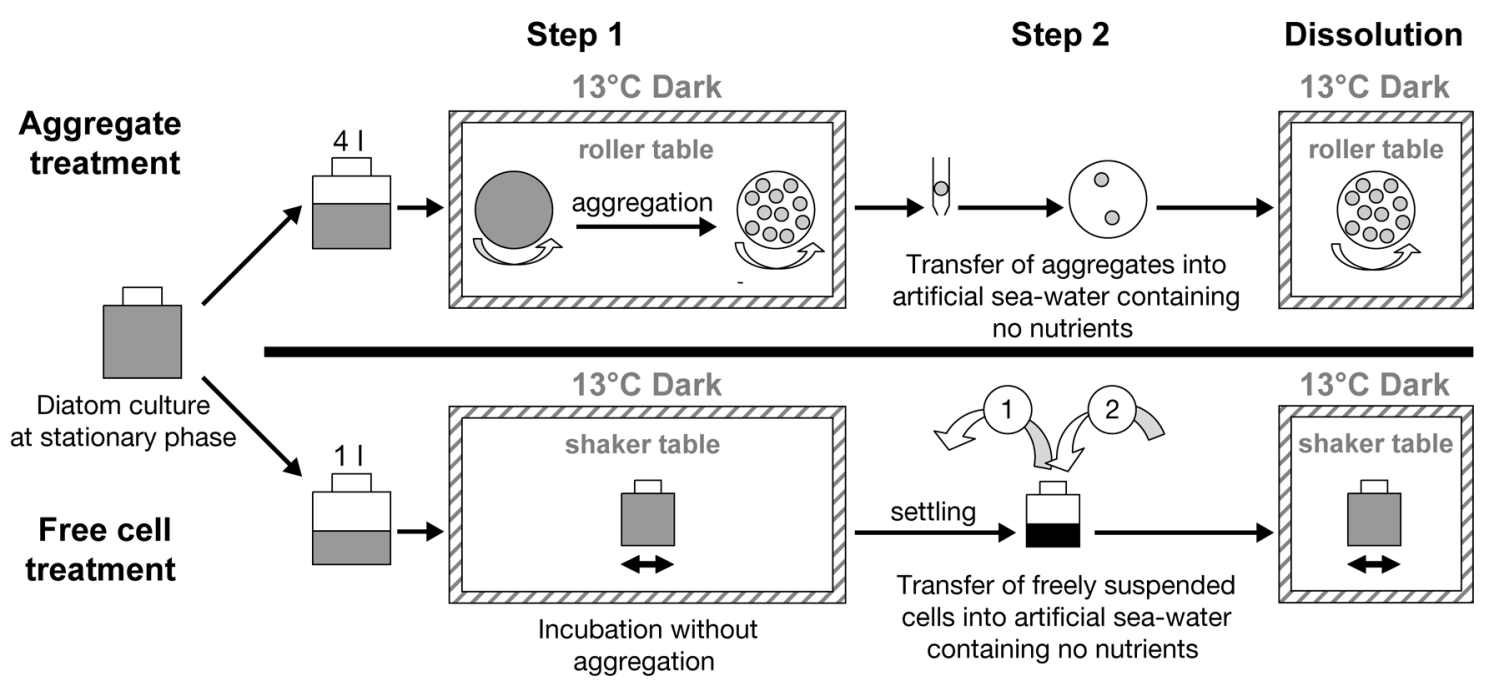

Fig. 1. Explanatory diagram of the set-up of the dissolution experiments. In Step 1, a dense batch culture was grown; one aliquot of this culture was transferred into a $4 \mathrm{l}$ rolling tank (preparation for aggregate treatment), and a second aliquot was incubated in a 11 flask on a shaker table (preparation for freely suspended cell treatment). During Step 2, aggregates collected from the roller tank were isolated and transferred into a smaller roller tank filled with artificial seawater without nutrients. Freely suspended cells were allowed to sediment, and the overlying medium was carefully exchanged for nutrient-free artificial seawater. During the dissolution experiment itself, aggregates were once again incubated on a roller table and freely suspended cells were kept dispersed and in suspension by mild shaking on a shaker table. During all phases both treatments were incubated at $13^{\circ} \mathrm{C}$ and, except the growth phase of the culture before Step 1, in the dark

ied from 100 to $500 \mathrm{~mm}^{3}$ in different experiments (see Table 2, Column 9).

Before each $\mathrm{bSiO}_{2}$ dissolution experiment, aggregated and freely suspended cells were transferred into artificial seawater containing no nutrients (Fig. 1, Step 2). A $50 \mathrm{ml}$ plastic pipette, with the tip cut off and smoothed, was used to isolate and transfer aggregates individually without breakage. Aggregate treatments were prepared by transferring a precise number of aggregates (60 to 150 each, depending on the size of the aggregates) into 21 cylindrical rolling tanks filled with artificial seawater containing no nutrients. Diatoms for the freely suspended cell treatments were transferred into artificial seawater containing no nutrients by allowing freely suspended cells to settle for 8 to $30 \mathrm{~h}$, until the majority of the diatoms resided at the bottom of the flask. The overlying medium was then carefully replaced with the artificial seawater that contained no nutrients. Filtration of diatoms was avoided because of the risk of diatom aggregation, breakage, or lysis.

Set-up of experiments. At the beginning of each dissolution experiment, 5 to 12 aggregates were isolated; their $\mathrm{bSiO}_{2}$ and TEP content and bacterial and diatom numbers were determined.

The $\mathrm{bSiO}_{2}$ dissolution experiments were conducted in the dark at $13^{\circ} \mathrm{C}$ on a roller table (aggregate treatments) or a shaker table (freely suspended cell treatments). Rotation speed of roller tanks was adjusted to ensure that aggregates remained in suspension, rather than hitting container walls, and it varied between 0.4 and $1.0 \mathrm{rpm}$; the shaker table oscillated at $2.9 \mathrm{~Hz}$. Experiments were conducted in the dark to mimic sinking through deep waters, to inhibit growth of diatoms, and to limit diatom utilization of newly dissolved $\mathrm{bSiO}_{2}$ (Blank \& Sullivan 1979). Experiments lasted for 3 to 32 d each.

During each experiment, the concentration of $\mathrm{dSi}$ in the surrounding seawater was measured every 1 to $2 \mathrm{~d}$. As part of the original medium was transferred together with aggregates or freely suspended cells into the nutrient-free artificial seawater, initial dSi concentrations varied for each treatment, averaging about $20 \mu \mathrm{mol} \mathrm{l}^{-1}$. Samples from rolling tanks were taken via a syringe stuck through a silicon stopper in the lid. This allowed easy removal of $5 \mathrm{ml}$ samples for the determination of $\mathrm{dSi}$ concentration, without stopping the roller table or disturbing aggregates in any way. Samples were immediately filtered through $0.2 \mu \mathrm{m}$ syringe filters (Millex GP syringe-driven filter unit with PES membrane; Millipore) and stored in a refrigerator until analysis. A syringe was also used to subsample freely suspended cell treatments. Sampling began as soon as aggregate sizes had stabilized after aggregate transferal, i.e. as soon as processes of aggregation and disaggregation were balanced.

Determination of initial and final $\mathrm{bSiO}_{2}$ concentrations. The initial and final amounts of $\mathrm{bSiO}_{2}$ were difficult to assess in aggregate treatments, because variability between replicate aggregates was high 
Table 1. Heterogeneity of replicate aggregates is shown using replicate aggregates collected at the end of Expt 7 (Skeletonema costatum) as an example. DW: total dry weight; $\mathrm{bSiO}_{2}(\mathrm{DW})^{-1}$ : ratio of $\mathrm{bSiO}_{2}$ to the total dry weight; diatoms [bacteria] agg. $^{-1}$ : the number of diatoms [bacteria] per aggregate; TEP: transparent exopolymer particles; $\mathrm{n}$ : number of replicate aggregates analyzed for each parameter

\begin{tabular}{|lccccc|}
\hline & $\begin{array}{c}\mathrm{DW} \\
\left.(\mathrm{mg} \mathrm{agg.})^{-1}\right) \\
\mathrm{n}=12\end{array}$ & $\begin{array}{c}\mathrm{bSiO} 2 \\
(\mathrm{DW})^{-1}(\%) \\
\mathrm{n}=12\end{array}$ & $\begin{array}{c}\text { Diatoms } \\
\text { agg. }^{-1} \\
\mathrm{n}=10\end{array}$ & $\begin{array}{c}\text { TEP }\left(\mu g X_{\text {eq. }}\right. \\
\left.\text { agg. }^{-1}\right) \\
\mathrm{n}=6\end{array}$ & $\begin{array}{c}\text { Bacteria } \\
\text { agg. }^{-1} \\
\mathrm{n}=7\end{array}$ \\
\hline Mean value & 0.151 & 2.18 & $2.9 \times 10^{6}$ & 1.9 & $\begin{array}{l}4.7 \times 10^{10} \\
\text { Minimum value }\end{array}$ \\
Maximum value & 0.105 & 0.48 & $5.6 \times 10^{5}$ & 1.0 & $1.2 \times 10^{10}$ \\
$1.6 \times 10^{11}$
\end{tabular}

Dry weight: Filters were dried at 50 to $60^{\circ} \mathrm{C}$ and reweighed on a Mettler Toledo UMX2 with a precision of $0.1 \mu \mathrm{g}$.

Biogenic silica: $\mathrm{bSiO}_{2}$ was determined using a variation of the method by Ragueneau \& Tréguer (1994). As no lithogenic silica was present in algal cultures, the second digestion step using hydrofluoric acid was not necessary. Samples were digested in $20 \mathrm{ml}$ of $0.2 \mathrm{~mol} \mathrm{l}^{-1}$ $\mathrm{Na}(\mathrm{OH})$ for $3 \mathrm{~h}$ at $95^{\circ} \mathrm{C}$ to ensure the dissolution of all $\mathrm{bSiO}_{2}$ while keeping the solution far from solubility. After cooling, $5 \mathrm{ml}$ of $1 \mathrm{~mol} \mathrm{l}^{-1} \mathrm{HCl}$ was added before

(Table 1). It was therefore impossible to calculate the initial amount of $\mathrm{bSiO}_{2}$ in incubated aggregates reliably from the average amount of $\mathrm{bSiO}_{2}$ in the 10 to 20 replicate aggregates initially sampled. Thus, the initial amount of $\mathrm{bSiO}_{2}\left(\mathrm{bSiO}_{2 \_}\right)$was calculated for each treatment (Eq. 1) from its final $\mathrm{bSiO}_{2}$ concentration $\left(\mathrm{bSiO}_{2 \mathrm{f}}\right)$ and from the respective change in dSi concentration of the surrounding seawater $\left(\mathrm{dSi}_{\mathrm{Ssw}} \mathrm{f}-\right.$ $\left.\mathrm{dSi}_{\mathrm{Ssw}_{-} 0}\right)$, which represents the amount of $\mathrm{bSiO}_{2}$ dissolved during the experiment, such that:

$$
\mathrm{bSiO}_{2 \_0}=\mathrm{bSiO}_{2 \_} \mathrm{f}+\left(\mathrm{dSi}_{\mathrm{SSw}_{-} \mathrm{f}}-\mathrm{dSi}_{\mathrm{SSw}_{-} 0}\right)
$$

The final $\mathrm{bSiO}_{2}$ concentration was determined from dry weight (DW) using the ratio $\mathrm{bSiO}_{2}: \mathrm{DW}\left(\% \mathrm{bSiO}_{2}\right.$ per weight) measured from aliquots of the final sample solutions. To this end, the entire content of the tanks with aggregates was shaken to break up aggregates and replicate aliquots were sampled to determine the ratio of $\mathrm{bSiO}_{2}$ to the total weight in the final solution. The replication of this ratio was very good. The rest of the solution was filtered onto pre-weighed, $0.4 \mu \mathrm{m}$ polycarbonate filters and weighed to calculate the final total $\mathrm{bSiO}_{2}$ concentrations.

Analysis. Calculation of concentrations in aggregates: TEP, bacteria, etc. in aggregates were determined by analyzing 2 fractions separately; the respective concentration in the water surrounding the aggregates and the concentration in a sample containing aggregates dispersed in this surrounding seawater. Concentrations in aggregates were then calculated by subtraction, assuming that the volume of the surrounding seawater equaled the total volume of the aggregate slurry. Thus, amounts per aggregate given here are low estimates.

Filtration for dry weight and biogenic silica: Dry weight determinations were conducted on the same filters as the determinations of $\mathrm{bSiO}_{2}$. Between 5 and $10 \mathrm{ml}$ of sample containing 3 aggregates or 5 to $10 \mathrm{ml}$ of sample water from treatments of freely suspended cells were filtered onto pre-weighed, $0.4 \mu \mathrm{m}$ polycarbonate filters. centrifugation and analysis of the dSi concentration.

Dissolved silicon: dSi concentrations were determined in samples filtered using $0.2 \mu \mathrm{m}$ syringe filters according to the molybdate blue spectrophotometric method (Mullin \& Riley 1965), adapted by Tréguer \& Le Corre (1975) and modified by Gordon et al. (1993) to segmented flow colorimetry. A Technicon AutoAnalyzer (Bran and Luebbe) was used.

Calculation of $\mathrm{bSiO}_{2}$ dissolution rates: Different possibilities exist to calculate $\mathrm{bSiO}_{2}$ dissolution rate from batch experiments. We used the linear initial rate approach described in the comparative study of Greenwood et al. (2001). The initial specific $\mathrm{bSiO}_{2}$ dissolution rate $\left(R\right.$, in nmol $\mathrm{Si} \mathrm{s}^{-1} \mathrm{~g}_{\mathrm{bSiO}}{ }_{2}^{-1}$ or in $\% \mathrm{~d}^{-1}$; see Table 2, Columns 5 and 6) was determined from the slope $\left(R^{\prime}\right.$, nmol $\left.l^{-1} \mathrm{~s}^{-1}\right)$ of the first linear part of the dSi change versus time (initial dissolution rate), normalized to the initial concentration of $\mathrm{bSiO}_{2}\left(w_{\mathrm{i}}\right.$, in $\mathrm{g} \mathrm{l}^{-1}$ or in $\mathrm{nmol} \mathrm{l}^{-1}$; with $1 \mu \mathrm{mol}=60 \mu \mathrm{g}_{\mathrm{bSiO}_{2}}$ ) such that:

$$
R=R^{\prime} / w_{\mathrm{i}}
$$

This initial phase ( 3 to 4 first data points after the dSi concentration started to increase) lasted for 5 to $10 \mathrm{~d}$.

Normalization of dissolution rates to initial $\mathrm{bSiO}_{2}$ concentration was necessary to compare experiments and treatments, as the increase of the dSi concentration depends on the initial amount of $\mathrm{bSiO}_{2}$ (Kamatani \& Riley 1979). It was impossible to start with exactly the same initial $\mathrm{bSiO}_{2}$ concentrations in all treatments (see Table 2, Column 4). We therefore present specific $\mathrm{bSiO}_{2}$ dissolution versus time to directly compare dissolution of aggregated and non-aggregated diatoms.

In addition to this initial specific dissolution rate, we calculated the daily specific dissolution based on the full duration of the dSi increase and will call this value the mean specific dissolution rate (see Table 2, Column 7). The amount of $\mathrm{bSiO}_{2}$ dissolved after $10 \mathrm{~d}$ (see Table 2, Column 8) was also calculated in treatments of sufficient duration.

Viability of diatoms: Viability of diatoms, i.e. the fraction of actively respiring cells, was assessed in a 
separate study using the FDA (fluorescein diacetate) method (Garvey et al. unpubl.). The staining solution was prepared directly before use by dilution (1:100) of the stock solution (50 mg of FDA in $10 \mathrm{ml}$ of dimethylsulfoxide) with distilled water. After adding $100 \mu \mathrm{l}$ of the FDA working solution to $9 \mathrm{ml}$ of diluted (3 times) sample of the aggregate treatments or to $3 \mathrm{ml}$ of undiluted sample of the freely suspended cells, the ratio of living (fluorescing green cells) to total cell numbers was determined under a Zeiss Axiovert fluorescence microscope. At least 200 diatoms were counted at a magnification of $200 \times$ in about 25 fields. Viability of cells was followed during the first $25 \mathrm{~d}$ of $\mathrm{bSiO}_{2}$ dissolution of aggregated and non-aggregated Thalassiosira weissflogii (Garvey et al. unpubl.).

TEP: Three replicate samples (3 to $6 \mathrm{ml}$ or 1 to 2 aggregates each), removed at the beginning and at the end of each dissolution experiment, were filtered onto $0.4 \mu \mathrm{m}$ polycarbonate filters and stained with $0.5 \mathrm{ml}$ of a $0.02 \%$ aqueous solution of Alcian blue in $0.06 \%$ acetic acid ( $\mathrm{pH} 2.5$ ) according to the method of Passow \& Alldredge (1995b). After $6 \mathrm{ml} 80 \% \mathrm{H}_{2} \mathrm{SO}_{4}$ was added, filters were soaked for $2 \mathrm{~h}$ and the absorption was measured at $787 \mathrm{~nm}$ in a $1 \mathrm{~cm}$ cuvette. Each working solution of Alcian blue was calibrated with Gum Xanthan. The units used are Gum Xanthan equivalents per aggregate $\left(\mu \mathrm{g} \mathrm{X}_{\text {eq. }} \mathrm{agg}^{-1}\right.$ ) for aggregate treatments and Gum Xanthan equivalents per liter $\left(\mu \mathrm{g} \mathrm{X}_{\text {eq. }}\right.$ $\mathrm{l}^{-1}$ ) for freely suspended cell treatments.

Bacterial abundance: The method used to count bacteria in aggregates was based on one proposed by Velji \& Albright (1993). Samples were diluted by a factor of 10 with $0.2 \mu \mathrm{m}$ filtered artificial seawater and fixed with formaldehyde to a final concentration of $10 \%$. To break aggregates, tetrasodium pyrophosphate was added (final concentration of 0.5 to $10 \mathrm{mmol} \mathrm{l}^{-1}$ ). Samples were vortexed several times during the $30 \mathrm{~min}$ incubation time at room temperature and then sonicated for $60 \mathrm{~s}$ with a microprobe sonicator (Level 3 to 4 ) to break aggregates. Detailed initial tests showed that this procedure did not result in cell breakage, but destroyed aggregates efficiently. After gentle filtration, bacteria were stained with 4',6-diamidino-2phenylindole (DAPI) for a final concentration of $1 \mu \mathrm{g}$ $\mathrm{ml}^{-1}$ (Velji \& Albright 1993) in samples from both the freely suspended cell and the aggregate treatments. Two replicate filters were prepared for each sample, and the numbers of bacteria were counted on each slide with a fluorescent microscope (Zeiss Axiovert). At least 300 bacteria per filter were counted in about 10 fields at a magnification of $1000 \times$. The use of ultrasonication, necessary for the disaggregation of the bacteria, prevented the enumeration of the fraction of bacteria attached to diatoms. Without ultra-sonication bacteria in aggregates were by far too dense to count.
Diatom counts: Samples were fixed with formaldehyde to a final concentration of $2 \%$ and enumerated within 1 mo. The use of a Coulter counter was impossible because of the presence of micro-aggregates and chains. Thus, diatoms were enumerated using an inverted microscope (Zeiss) following the method of Utermöhl (1958). Utermöhl chambers were filled directly with about $3 \mathrm{ml}$ of 10 - to 20 -fold diluted samples, and cells were allowed to settle for 2 to $3 \mathrm{~h}$ before enumeration. At least 300 cells were counted per sample at a magnification of 63 to $250 \times$.

Determination of dSi concentration in the pore water of aggregates: Concentrations of dSi in the pore water of aggregates were determined in 5 replicate aggregates at the end of Treatment $7 \mathrm{a}$ with Skeletonema costatum and in 10 replicate aggregates of Chaetoceros decipiens. The volume $\left(V_{\mathrm{a}}\right)$ of each individual aggregate was determined from its width $\left(W_{\mathrm{a}}\right)$ and length $\left(L_{\mathrm{a}}\right)$, measured under a binocular microscope (magnification 10 to $25 \times$ ). Each aggregate was transferred into a $50 \mathrm{ml}$ polycarbonate tube filled with $40 \mathrm{ml}$ of artificial seawater (to a total volume of $50 \mathrm{ml}$ ). Then the artificial seawater surrounding the aggregate was carefully sampled and filtered to determine its dSi concentration $\left(\mathrm{dSi}_{\text {sswi }} \mu_{\mathrm{mol}} \mathrm{l}^{-1}\right)$. The tube was subsequently shaken to break the aggregate and mix the pore water of the aggregate with the surrounding artificial seawater. This solution was sampled again, filtered through $0.4 \mu \mathrm{m}$ filters, and the dSi concentration was measured $\left(\mathrm{dSi}_{\text {toti }}\right.$ $\mu \mathrm{mol}^{-1}$ ). Using this method, the elevated dSi concentrations in the boundary layer of the aggregates are sampled together with the surrounding seawater, and measurements of pore water dSi concentration are corrected for elevated $\mathrm{dSi}$ concentrations in the boundary layer of the aggregates.

The number of diatoms $(n)$ was also counted, and the average diatom volume $\left(V_{\mathrm{c}} \mathrm{mm}^{3}\right)$ was calculated from the average diatom width $\left(W_{\mathrm{c} i} \mathrm{~mm}\right)$ and length $\left(L_{\mathrm{c} i}\right.$ $\mathrm{mm}$ ) as determined by measuring 10 diatoms (Eq. 3). The porosity $(p)$ was calculated from the cell numbers in each aggregate and from the volume of cells ( $V_{\mathrm{c} i}$ $\mathrm{mm}^{3}$ ) and of aggregates $\left(V_{\mathrm{a} i} \mathrm{~mm}^{3}\right)$ using Eqs. (3) \& (4). This calculation assumes the volume of TEP in aggregates to be negligible. The concentration of silicic acid inside the aggregate $\left(\mathrm{dSi}_{\text {aggi }} \mu \mathrm{mol} \mathrm{l}^{-1}\right)$ was then calculated from Eq. (5). The calculated silicic acid concentrations in pore water are conservative estimates, as the presence of TEP decreases the value of the true porosity compared to the assumed porosity. The calculations were performed such that:

$$
\begin{gathered}
V_{\mathrm{a} / \mathrm{c}}=\pi / 6 \times W_{\mathrm{a} / \mathrm{c}}^{2} \times L_{\mathrm{a} / \mathrm{c}} \\
p=\left(V_{\mathrm{a}}-n \times V_{\mathrm{c}}\right) / V_{\mathrm{a}} \\
\mathrm{dSi}_{\mathrm{agg}}=\left(\mathrm{dSi}_{\text {tot }}-\mathrm{dSi}_{\mathrm{ssw}}\right) \times 0.05 /\left(V_{\mathrm{a}} \times \mathrm{p}\right)
\end{gathered}
$$




\section{RESULTS}

\section{Specific $\mathrm{bSiO}_{2}$ dissolution rates}

Intraspecific comparison (aggregated vs. non-aggregated cells)

Because of species-specific differences in $\mathrm{bSiO}_{2}$ dissolution rates of diatoms, the specific dissolution rates of aggregated cells were compared to those of nonaggregated cells of the same species (Table 2). Results of 1 representative experiment per species (of the 2 to 3 conducted for each) are presented in Fig. 2, which shows the percent of $\mathrm{bSiO}_{2}$ that dissolved over time and the regressions that represent the initial specific dissolution rates $\left(\mathrm{d}^{-1}\right)$. As the dissolution rate may also vary with the physiological health of cells, only treatments stemming from the same experiment are compared in each figure.

Thalassiosira weissflogii. Two strains of $T$. weissflogii, differing in their aggregation behavior and production of TEP, were used. Strain 1 generated high TEP concentrations $\left(15000 \mu g \mathrm{X}_{\text {eq. }} \mathrm{l}^{-1}\right)$, but did not aggregate well. After $1 \mathrm{mo}$, all diatoms had aggregated, including diatoms kept on the shaker table. Two experiments with 2 treatments each $(1 \mathrm{a}, 1 \mathrm{~b}, 2 \mathrm{a}, 2 \mathrm{~b}$; Table 2$)$ were conducted with these aggregates formed from senescent diatoms, but no freely suspended cell treatments were possible. Diatoms from Strain 2 aggregated relatively quickly, within 2 to $3 \mathrm{~d}$ on the roller table, and remained non-aggregated on the shaking table. TEP concentrations from this strain were lower, around $7700 \mu \mathrm{g} \mathrm{X}$ eq. $\mathrm{l}^{-1}$. These cells were used for Expt 3.

Table 2. Summary of results (Agg: aggregate treatment; FC: freely suspended cell treatment). Treatments denoted with the same number (same experiment), but different letter (Column 2) were conducted simultaneously from the same batch culture, i.e. cells were in nearly the same physiological state. Column 4 depicts the initial biogenic silica $\left(\mathrm{bSiO}_{2}\right)$ concentration in each treatment. Column 5 lists the initial specific silica dissolution rates calculated from the regression of the first 3 to 4 points of the first linear part of the curve depicting dissolved silica $(\mathrm{dSi}$ ) over time in nanomoles of silica per liter per second normalized to the initial $\mathrm{bSiO}_{2}$ concentration in grams per liter. Column 6 shows the same values expressed in percent dissolution per day. Column 7 also depicts specific dissolution rates, but based on the whole dissolution period for each experiment, rather than on the regression of the initial linear part only. Experimental duration used for the calculations is given in brackets in days. Column 8 presents relative dissolution (in \%) during the first $10 \mathrm{~d}$ of the experiments. Column 9 lists the mean size of aggregates (NV: no value)

\begin{tabular}{|c|c|c|c|c|c|c|c|c|}
\hline 1 & 2 & 3 & 4 & 5 & 6 & 7 & 8 & 9 \\
\hline Species & $\begin{array}{l}\text { Expt } \\
\text { no. }\end{array}$ & $\begin{array}{l}\text { Type of } \\
\text { treatment }\end{array}$ & $\begin{array}{c}\text { Initial } \mathrm{bSiO}_{2} \\
\text { concentr. } \\
\left(\mathrm{mg} \mathrm{l}^{-1}\right)\end{array}$ & $\begin{array}{c}\text { Initial specific } \\
\text { dissolution rate } \\
\left(\mathrm{nmol} \mathrm{s}^{-1} \mathrm{~g}_{\mathrm{bSiO}}{ }^{-1}\right)\end{array}$ & $\begin{array}{c}\text { Initial specific } \\
\text { dissolution rate } \\
\qquad\left(\% \mathrm{~d}^{-1}\right)\end{array}$ & $\begin{array}{c}\text { Mean specific } \\
\text { dissolution rate } \\
\qquad\left(\% \mathrm{~d}^{-1}\right)\end{array}$ & $\begin{array}{c}\% \mathrm{bSiO}_{2} \\
\text { lost after } \\
10 \mathrm{~d}\end{array}$ & $\begin{array}{c}\text { Mean size } \\
\text { of aggregates } \\
\left(\mathrm{mm}^{3}\right)\end{array}$ \\
\hline \multicolumn{9}{|c|}{ Thalassiosira weissflogii } \\
\hline \multirow[t]{5}{*}{ Strain 1} & $1 \mathrm{a}$ & Agg & 0.3 & 4.6 & 2.4 & $2.4(7 \mathrm{~d})$ & NV & 97 \\
\hline & $1 b$ & Agg & 0.3 & 8.3 & 4.3 & $3.5(7 \mathrm{~d})$ & NV & 97 \\
\hline & $2 a$ & Agg & 0.2 & 5.1 & 2.7 & $1.3(3 \mathrm{~d})$ & NV & 97 \\
\hline & $2 \mathrm{~b}$ & Agg & 0.1 & 4.9 & 2.5 & $2.7(3 \mathrm{~d})$ & NV & 97 \\
\hline & Average & Agg & & $5.7 \pm 1.7$ & $3.0 \pm 0.9$ & & & \\
\hline \multicolumn{9}{|c|}{ Thalassiosira weissflogii } \\
\hline \multirow[t]{2}{*}{ Strain 2} & 3а & Agg & 6.9 & 10.4 & 5.4 & $2.3(30 \mathrm{~d})$ & 35.8 & NV \\
\hline & $3 b$ & $\mathrm{FC}$ & 7.5 & 20.0 & 10.4 & $1.1(30 \mathrm{~d})$ & 66.4 & NV \\
\hline \multicolumn{9}{|c|}{ Chaetoceros decipiens } \\
\hline & $4 a$ & Agg & 2.3 & 4.5 & 2.3 & $1.6(12 \mathrm{~d})$ & 15.9 & 125 \\
\hline & $4 \mathrm{~b}$ & Agg & 0.7 & 5.6 & 2.9 & $0.8(9 \mathrm{~d})$ & 7.5 & 125 \\
\hline & $4 \mathrm{C}$ & $\mathrm{FC}$ & 4.0 & 10.5 & 5.4 & $3.3(10 \mathrm{~d})$ & 40.2 & - \\
\hline & $5 a$ & Agg & 2.9 & 3.9 & 2.0 & $1.4(9 \mathrm{~d})$ & 12.4 & 417 \\
\hline & $5 b$ & $\mathrm{FC}$ & 5.1 & 12.4 & 6.4 & $2.2(19 \mathrm{~d})$ & 28.3 & - \\
\hline & Average & Agg & & $4.6 \pm 0.9$ & $2.4 \pm 0.4$ & & 11.9 & \\
\hline & & FC & & $11.4 \pm 1.4$ & $5.9 \pm 0.7$ & & 34.2 & \\
\hline \multicolumn{9}{|c|}{ Skeletonema costatum } \\
\hline & $6 a$ & Agg & 1.0 & 2.3 & 1.2 & $1.0(3 \mathrm{~d})$ & NV & 221 \\
\hline & $6 \mathrm{~b}$ & Agg & 1.0 & 4.1 & 2.1 & $2.1(2 \mathrm{~d})$ & NV & 221 \\
\hline & $6 \mathrm{c}$ & $\mathrm{FC}$ & 4.6 & 14.5 & 7.5 & $4.3(5 \mathrm{~d})$ & 36.4 & - \\
\hline & $7 a$ & Agg & 1.2 & 10.9 & 5.6 & $1.5(11 \mathrm{~d})$ & 27.2 & NV \\
\hline & $7 b$ & Agg & 2.0 & 4.8 & 2.5 & $2.5(11 \mathrm{~d})$ & 20.6 & NV \\
\hline & $8 a$ & Agg & 2.9 & 3.4 & 1.8 & $3.6(18 \mathrm{~d})$ & 23.2 & 493 \\
\hline & $8 \mathrm{~b}$ & $\mathrm{FC}$ & 2.5 & 6.5 & 3.4 & $2.9(18 \mathrm{~d})$ & 36.1 & - \\
\hline \multirow{2}{*}{\multicolumn{2}{|c|}{ Average }} & Agg & & $3.6^{\mathrm{a}} \pm 1.0$ & $1.9^{a} \pm 0.5$ & & $23.7^{\mathrm{a}}$ & \\
\hline & & FC & & $10.5 \pm 5.6$ & $5.4 \pm 2.9$ & & 36.3 & \\
\hline
\end{tabular}




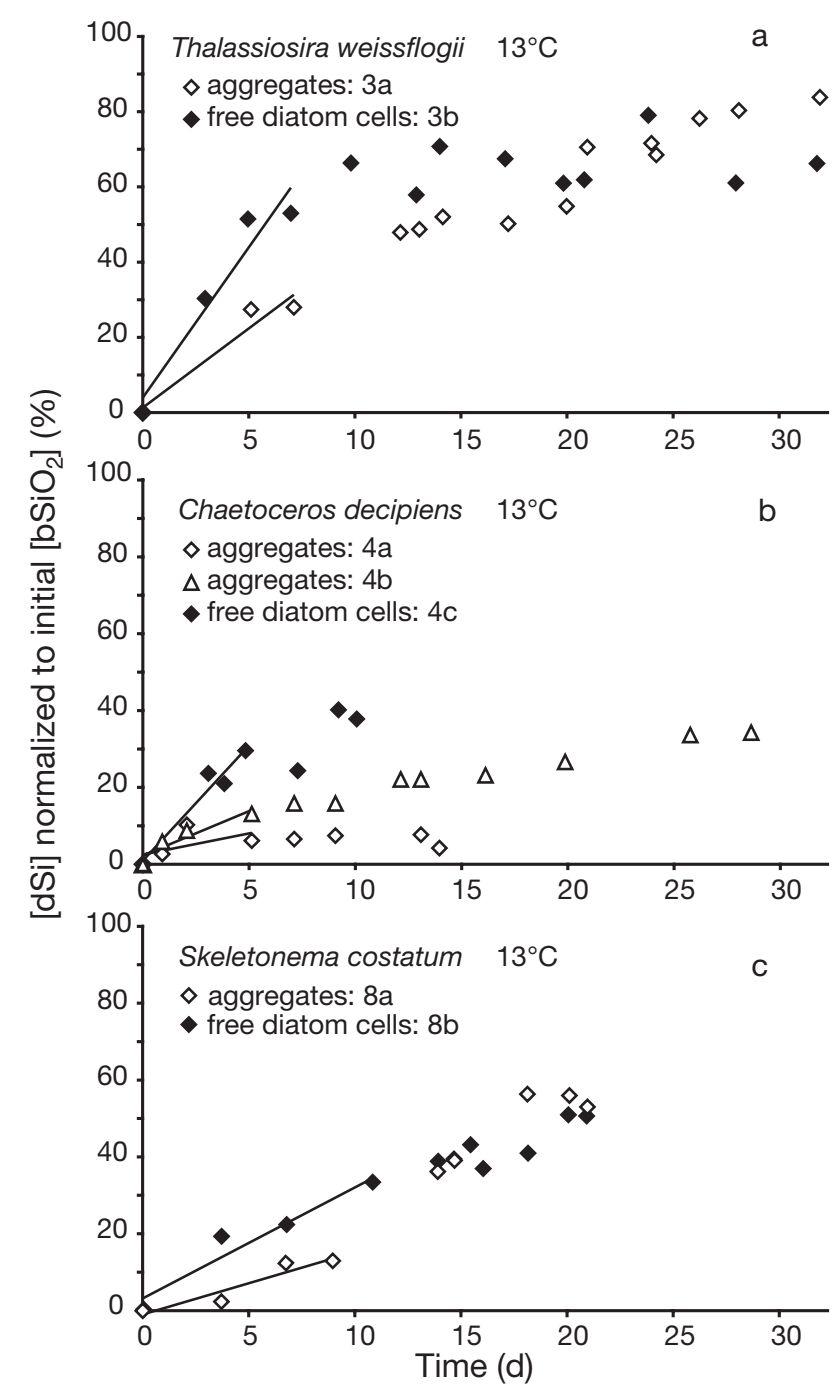

Fig. 2. Initial specific dissolution rate of biogenic silica $\left(\mathrm{bSiO}_{2}\right)$ versus time expressed as the increase in the concentration of dissolved silica [dSi] relative to $t=0$ (released $\mathrm{dSi}$ ) normalized to the concentration of initial $\mathrm{bSiO}_{2}$, in percent. (a) Expt 3a and b, with aggregated $(\diamond)$ and freely suspended ( $\bullet$ Thalassiosira weissflogii. (b) Expt 4a and b, with Chaetoceros decipiens aggregates $(\diamond, \Delta)$, and Expt $4 \mathrm{c}$, with freely suspended $C$. decipiens $(\diamond)$. (c) Expt 8a and b, respectively, with aggregated $(\diamond)$ and freely suspended $(\diamond)$ Skeletonema costatum. Regression lines (least-square fits) were calculated for the initial time period when dSi increase was linear, and were not forced through zero. Each graph represents data from 1 experiment only, which means that cells originated from the same batch and were physiologically speaking identical-except for the status of aggregation

The initial specific dissolution rate of $\mathrm{bSiO}_{2}$ in aggregates of Expt 3 was $5.4 \% \mathrm{~d}^{-1}\left(10.4 \mathrm{nmol} \mathrm{s}{ }^{-1} \mathrm{~g}_{\mathrm{bSiO}_{2}}{ }^{-1}\right)$, while the respective value of freely suspended cells was twice that $\left(10.4 \% \mathrm{~d}^{-1} ; 20.0 \mathrm{nmol} \mathrm{s} \mathrm{g}^{-1} \mathrm{~g} \mathrm{biO}_{2}{ }^{-1}\right)$ (Fig. 2a). After $10 \mathrm{~d}$ only $36 \%$ of the initial $\mathrm{bSiO}_{2}$ had dissolved if diatoms were aggregated, whereas $66 \%$ of the initial $\mathrm{bSiO}_{2}$ had dissolved from freely suspended cells. After $21 \mathrm{~d}$ the dissolution rate of aggregated diatoms had increased so that the dissolution curves intersect (Fig. 2a). At the end of the experiment, after $32 \mathrm{~d}, 84 \%$ of the initial $\mathrm{bSiO}_{2}$ was dissolved in treatments with aggregates, whereas only $70 \%$ of the initial $\mathrm{bSiO}_{2}$ was dissolved in the treatment with freely suspended cells.

In Expts 1 and 2, dSi concentrations decreased during the first 24 to $48 \mathrm{~h}$, suggesting growth of Thalassiosira weissflogii. Light exposure during transferal of aggregates and handling during preparations for the experiment may have sufficed to initiate this growth surge. Time zero for the calculations of $\mathrm{bSiO}_{2}$ dissolution rates was set to Day 2, when growth had ceased. The initial specific $\mathrm{bSiO}_{2}$ dissolution rates of the 4 aggregated treatments with Strain 1 were appreciably lower than that of Expt 3 and averaged $3.0 \pm 0.9 \% \mathrm{~d}^{-1}$ $\left(5.7 \pm 1.7 \mathrm{nmol} \mathrm{s}^{-1} \mathrm{~g}_{\mathrm{bSiO}_{2}}{ }^{-1}\right)$.

Chaetoceros decipiens. The initial specific $\mathrm{bSiO}_{2}$ dissolution rates of aggregated $C$. decipiens (Treatments $4 \mathrm{a}$ and $\mathrm{b}$ ) were also lower than those of the freely suspended cells (Treatment $4 \mathrm{c}$ ) of the same experiment (Fig. 2b). About $40 \%$ of C. decipiens used in Expt 4 was initially viable and thus differed physiologically from those of Expt 5, where initially $60 \%$ of cells was viable. As in Expt 4, initial specific $\mathrm{bSiO}_{2}$ dissolution rates of aggregated $C$. decipiens of Expt 5 were lower than those of freely suspended cells. Thus, on average, the initial specific dissolution rates of aggregated cells of C. decipiens $\left(2.4 \pm 0.4 \% \mathrm{~d}^{-1}\right.$ or $4.6 \pm 0.9 \mathrm{nmol} \mathrm{s}{ }^{-1}$ $\mathrm{g}_{\mathrm{bSiO}}{ }_{2}^{-1}$ ) were substantially lower (2.5-fold) than the respective rate of freely suspended cells $(5.9 \pm 0.7 \%$ $\mathrm{d}^{-1}$ or $11.4 \pm 1.4 \mathrm{nmol} \mathrm{s}^{-1} \mathrm{~g}_{\mathrm{bSiO}_{2}}{ }^{-1}$; Table 2). During the first $10 \mathrm{~d}$ of dissolution, an average of $12 \%$ of the initial $\mathrm{bSiO}_{2}$ was dissolved in treatments with aggregated $C$. decipiens, whereas, on average, $34 \%$ of the initial $\mathrm{bSiO}_{2}$ was dissolved in the respective treatments with freely suspended cells.

Skeletonema costatum. $\mathrm{bSiO}_{2}$ dissolution was determined in 5 treatments with $S$. costatum aggregates (6a, $6 \mathrm{~b}, 7 \mathrm{a}, 7 \mathrm{~b}, 8 \mathrm{a})$ and $2(6 \mathrm{c}, 8 \mathrm{~b})$ treatments with freely suspended $S$. costatum (Table 2). Expts 6 and 7 were conducted with batches that aggregated within 1 to $2 \mathrm{~d}$ after transferal to the roller table, whereas the batch used for Expt 8 needed $10 \mathrm{~d}$ to form aggregates.

On average, the initial specific $\mathrm{bSiO}_{2}$ dissolution rate of all 4 treatments with Skeletonema costatum aggregates was $2.6 \pm 0.5 \% \mathrm{~d}^{-1}\left(5.1 \pm 2.6 \mathrm{nmol} \mathrm{s}^{-1} \mathrm{~g}_{\mathrm{bSiO}}{ }_{2}^{-1}\right)$, or $1.9 \pm 0.5 \% \mathrm{~d}^{-1}\left(3.6 \pm 1.0 \mathrm{nmol} \mathrm{s}{ }^{-1} \mathrm{gbSiO}_{2}{ }^{-1}\right)$ if Treatment $7 \mathrm{a}$, in which the initial dissolution rate was very high compared to that of the other treatments, is excluded. The respective value for the non-aggregated treatments was appreciably higher than both values, with an average of $5.4 \pm 2.9 \% \mathrm{~d}^{-1}\left(10.5 \pm 5.6 \mathrm{nmol} \mathrm{s} \mathrm{s}^{-1}\right.$ 
$\mathrm{g}_{\mathrm{bSiO}_{2}}{ }^{-1}$; Table 2). Accordingly, an average of $24 \%$ of the initial $\mathrm{bSiO}_{2}$ concentration dissolved during the first $10 \mathrm{~d}$ in aggregated treatments of $S$. costatum, whereas $36 \%$ of the $\mathrm{bSiO}_{2}$ dissolved in the respective treatments with freely suspended cells during the same time period. In Expt 8 (Fig. 2c), which lasted 21 d, the relative dissolution of aggregated cells surpassed that of freely suspended cells after $15 \mathrm{~d}$, with a dissolution of 63 and $53 \%$ of the initial $\mathrm{bSiO}_{2}$ for aggregated and non-aggregated cells, respectively.

Variability due to interspecific and physiological differences

Data from all experiments are shown in Fig. 3. Initial specific $\mathrm{bSiO}_{2}$ dissolution rates of aggregate treatments (13 treatments) were all similar and $<5 \% \mathrm{~d}^{-1}$, except in Expts 3a $\left(5.4 \% \mathrm{~d}^{-1}\right)$ and $7 \mathrm{a}\left(5.6 \% \mathrm{~d}^{-1}\right)$, whereas those of freely suspended cells were $>5 \% \mathrm{~d}^{-1}$ in all experiments, except in Expt 8b, where an initial specific rate of $3.4 \% \mathrm{~d}^{-1}$ was determined (Fig. 3a). The MannWhitney $W$-test was used to statistically verify if the specific $\mathrm{bSiO}_{2}$ dissolution rates of aggregated and freely suspended cells differed significantly independent of species-specific or physiological differences. All treatments and experiments were included in the statistical analysis. The median of the initial specific $\mathrm{bSiO}_{2}$ dissolution rate of the 13 aggregate treatments was $2.5 \% \mathrm{~d}^{-1}$, whereas that of the 5 treatments with freely suspended cells was $6.4 \% \mathrm{~d}^{-1}$, resulting in a probability of $0.0058(W=61.0)$ that the initial specific dissolution rates of both treatment types were equal. This means that the initial specific dissolution rate of aggregated diatoms was statistically significantly lower compared to that of freely suspended cells, despite the high variability between species, the impact of physiological stage and age, and despite the large heterogeneity between replicate aggregates. A difference in the fraction of $\mathrm{bSiO}_{2}$ dissolved after $10 \mathrm{~d}$ was also obvious between treatment types, although here too variability was high within each type of treatment (Fig. 3b). The difference in the $\mathrm{bSiO}_{2}$ dissolution rate depending on the aggregation state was less pronounced and not significant at $95 \%$, when the specific dissolution rate was calculated over longer time periods (over $14 \mathrm{~d}$ ), because after $14 \mathrm{~d}$ $\mathrm{bSiO}_{2}$ dissolution of aggregated diatoms surpassed that of freely suspended cells.

\section{Changes over time}

Specific dissolution rates depended on the time interval for which they were calculated. A comparison of Columns 6, 7 and 8 of Table 2 for each experiment

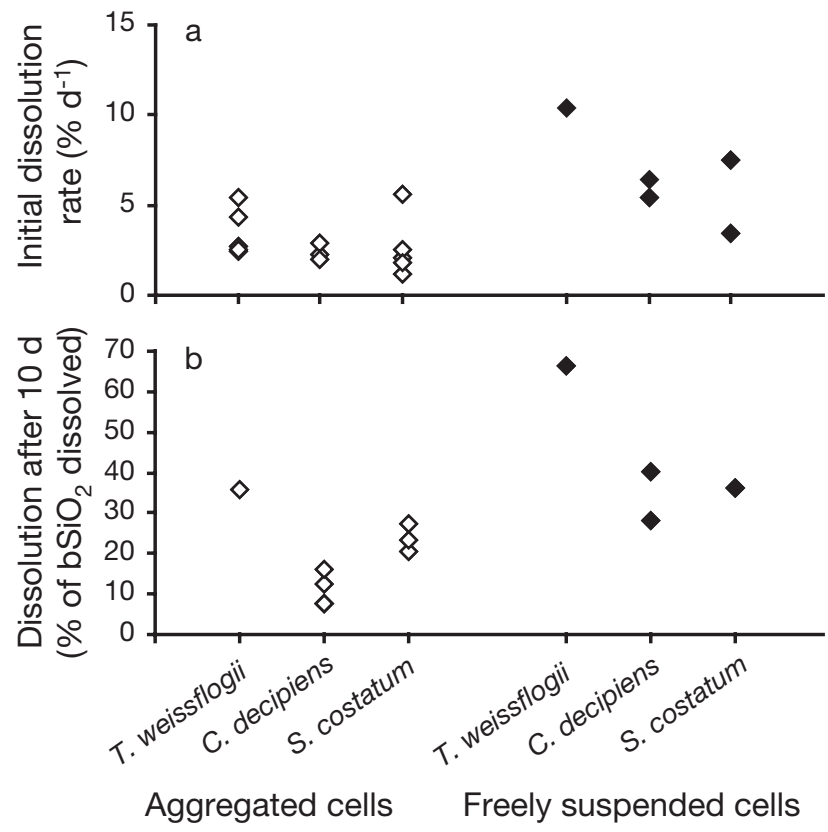

Fig. 3. Comparison of (a) initial specific dissolution rates and (b) specific dissolution after $10 \mathrm{~d}$ for aggregated $(\diamond, \mathrm{n}=5,3,5)$ and freely suspended $(\bullet, \mathrm{n}=1,2,2)$ treatments of Thalassiosira weissflogii, Chaetoceros decipiens and Skeletonema costatum, respectively. More experiments with aggregated cells were conducted, as the variability between replicate aggregates was high. In (b) both data points of $\mathrm{bSiO}_{2}$ dissolution of free cells of $S$. costatum lie on top of each other. Estimates of $\mathrm{bSiO}_{2}$ dissolution using either calculation method show a statistically significant (see 'Results: Variability due to interspecific and physiological differences') lower specific dissolution rate when cells are aggregated, although variability due to physiological and species-specific differences, as

well as due to variability of replicate aggregates, is high

shows that specific dissolution rates decreased with time, except for the aggregated cell treatment (8a). In contrast to the other experiments, specific dissolution rates in Treatment 8a increased considerably with time (doubling from initially $1.8 \mathrm{~d}^{-1}$ to a mean rate of $3.6 \mathrm{~d}^{-1}$ over $18 \mathrm{~d}$ ). In Expts 3 and 8, the only 2 experiments in which the aggregated treatments were followed for $>2 \mathrm{wk}$, specific dissolution rates of aggregated diatoms decreased less with time than those of freely suspended cells. After $2 \mathrm{wk}$, specific dissolution rates of aggregated diatoms surpassed those of freely suspended cells.

\section{dSi concentration in the pore water of aggregates}

$\mathrm{dSi}$ concentration in the pore water of 5 aggregates, sampled at the end of Treatment $7 \mathrm{~b}$, ranged from 9 to $180 \mu \mathrm{mol} \mathrm{l}^{-1}$, whereas the dSi in the surrounding water was $6 \mu \mathrm{mol} \mathrm{l}^{-1}$ at the beginning and $13 \mu \mathrm{mol} \mathrm{l}^{-1}$ at the end of the experiment. The average porosity of these aggregates was about $99.9 \%$, ignoring the presence of 
TEP. TEP is thought to occupy about $5 \%$ of the aggregate volume (Passow 2002a), and its impact on effective porosity is unclear. The dSi pore water concentration of 10 Chaetoceros decipiens aggregates, which were $48 \mathrm{~h}$ old, ranged from 80 to $230 \mu \mathrm{mol} \mathrm{l}^{-1}$, with a surrounding seawater concentration $<20 \mu \mathrm{mol} \mathrm{l}^{-1}$. The porosity of these aggregates was $99.8 \%$, excluding TEP.

\section{Transparent exopolymer particles}

The concentration of TEP within aggregates varied by $>1$ order of magnitude, between 0.6 and $15 \mu g X_{\text {eq. }}$. agg. ${ }^{-1}$, without consistent difference due to species. TEP concentration in the freely dispersed cell treatments did not show any consistent differences between species either, and averaged around $10 \mathrm{mgX}$ eq. $\mathrm{l}^{-1}$. Whereas no correlation could be found between $\mathrm{bSiO}_{2}$ dissolution and TEP concentration in treatments with freely suspended cells, the initial specific $\mathrm{bSiO}_{2}$ dissolution rate of aggregated cells was a function of TEP concentration in aggregates, independent of the species making up the aggregate (Fig. 4). A higher TEP content reduced the initial specific $\mathrm{bSiO}_{2}$ dissolution rate.

\section{Bacteria}

The concentration of bacteria in Expts 6 and 7 in aggregated and freely suspended cell treatments fluctuated over time without trend, but was very high, ranging from $1.2 \times 10^{10}$ to $1.6 \times 10^{11}$ bacteria agg. ${ }^{-1}$ and $1.2 \times$ $10^{10}$ to $2.0 \times 10^{10}$ bacteria $\mathrm{ml}^{-1}$, respectively. Bacterial abundances in aggregates are difficult to compare directly to those of free-living forms as the fraction of total bacteria that is associated with aggregates depends heavily on aggregate concentration. As we were investigating the impact of bacteria on $\mathrm{bSiO}_{2}$ dissolution, the bacterial abundance in relation to diatom concentration is important. The number of bacteria normalized to the number of diatoms was similar or lower in aggregate treatments, with, on average, $9 \times 10^{4}$ bacteria diatom $^{-1}$ compared to treatments with freely suspended cells, with, on average, about $26 \times 10^{4}$ bacteria diatom $^{-1}$. However, the fraction of bacteria in close contact with diatoms (e.g. attached bacteria) is unknown. As it was necessary to disaggregate samples, attached bacteria could not be counted. Generally bacteria are not found on living diatoms, but colonize dead diatoms rapidly.

\section{Viability}

In a separate study, the change in viability of aggregated and dispersed Thalassiosira weissflogii over time

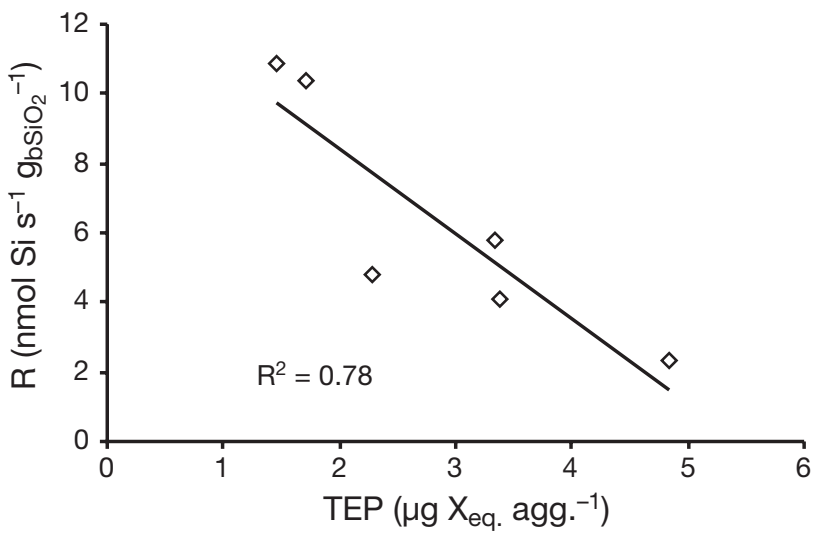

Fig. 4. Initial specific dissolution rate of $\mathrm{bSiO}_{2}$ in aggregates (Treatments 2a, 5a,6a, 6b, 7a, 7b) of Skeletonema costatum (4 experiments), Chaetoceros decipiens (1 experiment), and Thalassiosira weissflogii (1 experiment) as a function of transparent exopolymer particles (TEP) concentration in aggregates (regression line, $\mathrm{r}^{2}=0.78, \mathrm{n}=6$ experiments, $\mathrm{p}<0.05$ )

was followed during $25 \mathrm{~d}$ (Garvey et al. unpubl.) of a dissolution experiment (Fig. 5a, redrawn from Garvey et al. unpubl.). The experiment started with a diatom viability of $40 \%$ for both aggregated and freely suspended cells. Viability of freely suspended cells decreased continuously until a viability of only $5 \%$ was reached after 17 to $21 \mathrm{~d}$. The viability of aggregated cells, in contrast, remained $>30 \%$ for the first $13 \mathrm{~d}$. Only thereafter did viability of aggregated cells decrease, reaching $7 \%$ after about $25 \mathrm{~d}$ (Garvey et al. unpubl.).

Independent of treatment, the fraction of $\mathrm{bSiO}_{2}$ lost due to dissolution in both aggregated and freely suspended cell treatments was a function of the fraction of viable cells (Fig. 5b). The fraction of $\mathrm{bSiO}_{2}$ lost increased from 40 to near $80 \%$ as the fraction of actively respiring cells (viability) decreased from 40 to $5 \%$.

\section{DISCUSSION}

\section{Applicability of laboratory-determined specific $\mathrm{bSiO}_{2}$ dissolution rates to the ocean}

The size, weight, porosity, and TEP content of the aggregates made in roller tanks for these experiments were similar to those of natural aggregates. Alldredge et al. (1998) observed a large size range of natural aggregates, and measured sizes ranged from 0.005 to $1 \mathrm{~cm}^{3}$ agg. ${ }^{-1}$ and weights from 5 to $1000 \mu \mathrm{g} \mathrm{agg.}{ }^{-1}$. In our study, aggregates were less variable, with a size range of 0.1 to $1 \mathrm{~cm}^{3} \mathrm{agg}^{-1}$ and a weight between 187 and $622 \mu$ agg. $^{-1}$. The porosity of natural aggregates measured by Logan \& Alldredge (1989) was slightly higher (between 99.94 and $99.98 \%$ ) compared to our aggregates made on roller tables (99.80 to $99.92 \%$ ). 

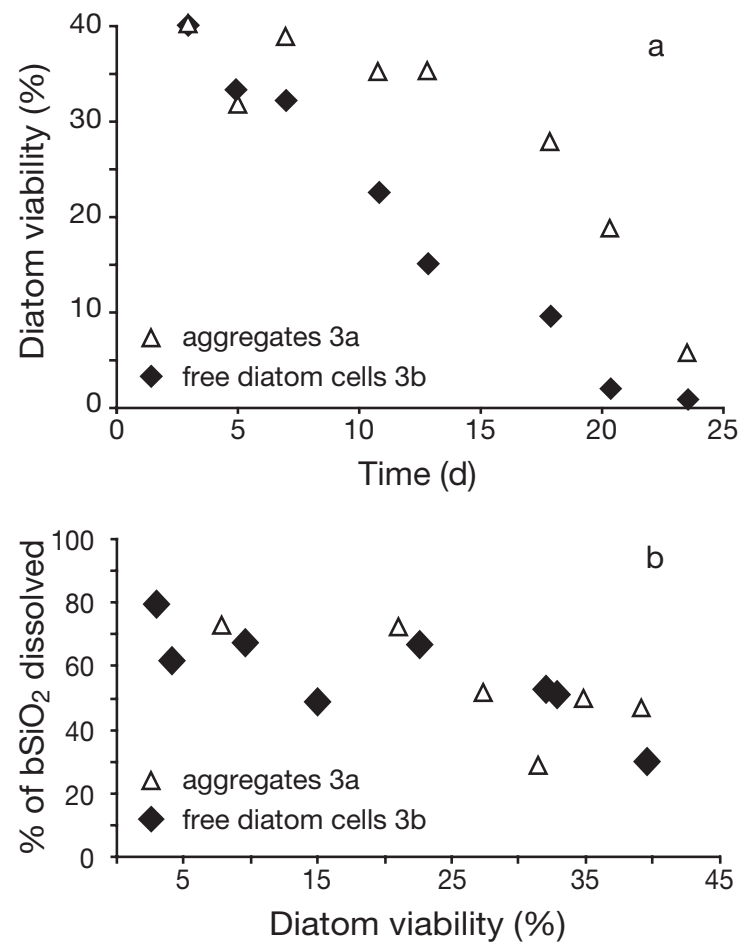

Fig. 5. (a) Decrease in viability of diatoms in aggregates $(\Delta)$ and freely suspended cells $(\diamond)$ versus time during a dissolution experiment with Thalassiosira weissflogii. Redrawn from Garvey et al. (unpubl.). (b) Fraction of $\mathrm{bSiO}_{2}$ dissolved ( $T$. weissflogii) as a function of viability, with data of both aggregated and freely suspended treatments included

Natural aggregates contain between 0.5 and $100 \mu g X_{\text {eq. }}$ agg. $^{-1}$ (Alldredge et al. 1998); the TEP concentrations of our aggregates ranged between 0.6 and $10 \mu g \mathrm{X}_{\text {eq. }}$. agg. $^{-1}$. Bacterial numbers ranged from $8.1 \times 10^{9}$ to $1.6 \times$ $10^{11}$ bacteria agg. ${ }^{-1}$, which is higher than the range observed on natural marine snow $\left(10^{6}\right.$ to $10^{8}$ bacteria agg. ${ }^{-1}$; Silver \& Alldredge 1981, Alldredge \& Youngbluth 1985, Alldredge et al. 1986). Concentrations of TEP and bacteria in freely suspended cell treatments were within the upper range of naturally occurring concentrations (Passow 2002a) and typical for non-growing dense batch cultures (Passow 2002b). Concentrations of aggregates and freely suspended cells in experiments had to be higher than commonly found in the ocean to be able to measure $\mathrm{bSiO}_{2}$ dissolution reliably.

In our experiments, changes in the concentrations of dSi over time in treatments with aggregates potentially resulted from a combination of factors: (1) dSi uptake by diatoms, (2) release of dSi from diatoms, (3) $\mathrm{bSiO}_{2}$ dissolution within aggregates, and (4) exchange of dSi between aggregates and the surrounding seawater. Uptake and release of dSi by cells is negligible after 1 to $2 \mathrm{~d}$ in the dark (Blank \& Sullivan 1979). Therefore, changes in dSi concentrations over time in treatments with aggregates reflect an apparent dissolution of $\mathrm{bSiO}_{2}$, i.e. true dissolution combined with transport of dSi through aggregates (diffusion and advective flow). In situ, dissolution and transport processes are also combined, so that this 'apparent dissolution' accurately reflects silica release into the water column and represents the value necessary to budget silica recycling during sinking.

The average initial specific $\mathrm{bSiO}_{2}$ dissolution rates measured for freely suspended cells $\left(6.6 \pm 2.6 \% \mathrm{~d}^{-1}\right.$ corresponding to $\left.24.2 \pm 9.5 \mathrm{yr}^{-1}\right)$ and aggregates $(2.9 \pm$ $1.1 \% \mathrm{~d}^{-1}$ corresponding to $10.0 \pm 4.2 \mathrm{yr}^{-1}$ ) are in the same range as the estimated global world average of $16 \mathrm{yr}^{-1}$ (Van Cappellen et al. 2002) and as in situ measurements compiled by Nelson et al. (1991), which ranged from 5 to $1000 \mathrm{yr}^{-1}$.

\section{Factors responsible for the difference in $\mathrm{bSiO}_{2}$ dissolution rates between aggregated and freely suspended cells}

In our study, initial specific $\mathrm{bSiO}_{2}$ dissolution rates of aggregated cells were 2 to 3 times lower than those of non-aggregated cells. The lower initial dissolution rates can be explained by a combination of factors, which are first discussed individually; thereafter their interaction will be addressed.

\section{dSi concentrations in pore water}

Average dSi concentrations in aggregate pore water were $100 \mu \mathrm{mol}^{-1}$, i.e. appreciably higher than dSi concentrations in the surrounding seawater, which averaged around $20 \mathrm{umol}^{-1}$ for all experiments. Brzezinski et al. (1997) also found the dSi concentrations in pore water of natural aggregates to be elevated (305 $\mu \mathrm{mol}$ $\mathrm{l}^{-1}$ ) compared to the dSi concentration of the surrounding seawater.

With natural dSi concentrations remaining far below saturation (solubilities of 1000 and $1500 \mu \mathrm{mol} \mathrm{l}^{-1}$ at temperatures of 5 and $15^{\circ} \mathrm{C}$, respectively; Van Cappellen \& Qiu 1997a,b), it has long been believed that the rate of $\mathrm{bSiO}_{2}$ dissolution in the water column would not be influenced by dSi concentrations. Van Cappellen \& Qiu (1997a,b), however, demonstrated nonlinearity between dissolution and dSi concentration. Far from equilibrium, at concentrations $<200 \mu \mathrm{mol} \mathrm{l}^{-1} \mathrm{a}$ small increase in dSi has a large effect on the dissolution rate. Although their curve does not extend to lower concentrations, their results indicate a large change in the dissolution rate with relatively small changes in dSi concentration in the range of dSi concentrations found in the ocean and used in our experi- 
ments. The elevated dSi concentrations measured in the aggregate pore water (around $100 \mu \mathrm{mol} \mathrm{l}^{-1}$ ) should therefore contribute to the slower dissolution of aggregated diatoms relative to non-aggregated diatoms.

\section{Viability}

Aggregation of cells has been suggested to represent an evolutionary adaptation for survival (Smetacek 1985, Gotschalk \& Alldredge 1989). The viability of Thalassiosira weissflogii is prolonged by aggregation (Garvey et al. unpubl.). An extended viability of aggregated diatoms is possibly due to the elevated nutrient concentrations found within aggregates (Shanks \& Trent 1980, Grossart \& Simon 1993), as high nutrient concentrations decrease cell mortality. Prolonged viability directly affects $\mathrm{bSiO}_{2}$ dissolution, because the frustules of living diatoms are protected against dissolution by an organic membrane (Patrick \& Holding 1985, Bidle \& Azam 1999). Consequently, bSiO ${ }_{2}$ dissolution rates in living cells are close to zero (Nelson et al. 1976). The dissolution of diatom frustules commences only after cells are senescent or dead, when the organic coating surrounding the diatom frustules is removed by bacteria or chemical cleaning (Kamatani 1982). In our experiment, viability of cells seemed to determine $\mathrm{bSiO}_{2}$ dissolution independent of the treatment, suggesting that the difference in viability was indeed responsible for the retardation of dissolution in aggregated cells (Fig. 5b). At the end of Expts 3 and 8, which lasted $>2$ wk, aggregated cells dissolved faster once aggregates aged. These observations suggest that aggregation of diatoms delays the dissolution of frustules rather than decreasing it. This is consistent with the impact of aggregation on diatom viability, which remains higher for longer within aggregates.

\section{Bacteria}

In nature, bacteria remove the protective organic layer after cells are senescent, and bacterial activity is a prerequisite for dissolution of diatom frustules (Patrick \& Holding 1985, Bidle \& Azam 1999, 2001). TEP form a good substrate for bacteria (Passow \& Alldredge 1994), and bacteria associated with aggregates are very concentrated and active (Smith et al. 1992). This could imply that the removal of the protective organic layer should be faster in aggregates, which, all other things being equal, would subsequently lead to faster dissolution of aggregated diatom frustules. We, however, found the opposite to be true; initial $\mathrm{bSiO}_{2}$ dissolution was slower in aggregates.
Bacterial numbers normalized to diatom numbers were, on average, slightly higher in the freely suspended cell treatments than in the aggregate treatments. But bacteria need to be closely associated with senescent or dead diatoms to be able to degrade the protective layer. We have no estimate of the fraction of bacteria directly attached to diatoms as preparations for counting bacteria disaggregated them. However, the relatively high ratio between bacteria and diatoms suggests that, upon senescence, diatoms could be populated rapidly by bacteria in both treatments. Thus, bacterial concentration or activity was probably not a rate-limiting step for $\mathrm{bSiO}_{2}$ dissolution. Rather than bacterial abundance, the lower fraction of senescent and dead diatoms in aggregates was presumably responsible for a lower degradation rate of the protective layer and thus the lower $\mathrm{bSiO}_{2}$ dissolution rate. This is confirmed by the relationship between $\mathrm{bSiO}_{2}$ dissolution and viability for aggregated and freely suspended diatoms. This relationship suggests that not aggregation per se, but increased viability of diatoms may be responsible for the reduced initial dissolution rate found in aggregated versus freely suspended cells.

\section{Transparent exopolymer particles}

Initial specific $\mathrm{bSiO}_{2}$ dissolution rates in aggregates were significantly correlated with the TEP content, even when aggregates consisting of different species were included (Fig. 4). The reduction of the initial $\mathrm{bSiO}_{2}$ dissolution rate with increasing TEP content, as well as elevated dSi concentrations in aggregate pore water, imply that TEP may play a role in decreasing dSi flux out of aggregates and therefore the initial $\mathrm{bSiO}_{2}$ dissolution rate of aggregated diatoms. A reduction of the diffusion of solutes through mucus-coated sediments compared to sediments in free solution has been attributed to both size and charge inhibition due to mucus (Hannides et al. 2005). Porous sediments covered with TEP-like mucus are to some extent comparable to marine snow-sized aggregates, although the porosity of aggregates is much higher. Possibly, chemically binding of dSi to TEP (Welch \& Vandevivere 1994, Welch \& Ullman 1993), charge restrictions, a lengthening of the diffusion pathway due to the fractal nature of diatom aggregates (Dachs \& Bayona 1998), or size-dependant permeability are responsible for the accumulation of $\mathrm{dSi}$ in aggregates. Alternatively, TEP may simply allow elevated dSi concentrations to build up by restricting advective flow, without impacting diffusion rates appreciably (Ploug \& Passow 2007). In all cases, TEP would contribute to the reduction of the apparent dissolution of $\mathrm{bSiO}_{2}$ by retaining dSi within aggregates. Higher dSi concentrations with- 
in aggregates not only reduce dissolution rates directly, but higher nutrient concentrations in general are presumably also responsible for the higher survival rate of diatoms inside aggregates. The higher viability of aggregated diatoms, in turn, protects the cells against bacterial degradation of the organic membrane and the onset of $\mathrm{bSiO}_{2}$ dissolution.

\section{Chain or colony formation}

It is interesting to note that within the freely suspended treatments the initial $\mathrm{bSiO}_{2}$ dissolution rate of Thalassiosira weissflogii was by far the highest compared to the other 2 species. Compared to Chaetoceros decipiens and Skeletonema costatum, which both form chains, individual $T$. weissflogii cells were farther apart from each other. The shape, size, and the degree of silicification of diatoms all impact dissolution rates. Our results indicate that the proximity to other diatoms, which is higher in chain-forming species compared to non-chain-forming species, may also impact $\mathrm{bSiO}_{2}$ dissolution rate. Elevated concentrations in the microenvironment (diffusive boundary layer) surrounding individual cells may affect neighboring diatoms of chain-forming species. Thus, chain formation, like aggregation, may be an adaptation to increase the proximity of diatoms to each other, which may enable the development of a micro-environment that promotes an increase in the overall viability of the population.

\section{Conclusions}

$\mathrm{bSiO}_{2}$ dissolution rates measured experimentally on laboratory-made aggregates and on freely suspended cells show evidence of a decreased specific $\mathrm{bSiO}_{2}$ dissolution rate within aggregates during the first $14 \mathrm{~d}$. This retardation of dissolution seems to occur because aggregates maintain a high dSi concentration $\left(>100 \mu \mathrm{mol} \mathrm{l}^{-1}\right.$ ) within their pore water, possibly due to the presence of TEP, which, in turn, extends the viability of aggregated diatoms compared to freely suspended cells. The possible effect of the retardation of diffusion due to TEP will be investigated further with the help of a model (Moriceau et al. unpubl.). A higher viability will inhibit bacterial degradation of the protective organic membrane. Apparently, in our experiment, the degradation of the protective layer after diatoms death was fast enough to have had little impact on the difference between $\mathrm{bSiO}_{2}$ dissolution rates measured in both treatments. Instead $\mathrm{bSiO}_{2}$ dissolution rate was a function of the viability of cells.

Our results bring interesting elements into the debate concerning the ecological role of aggregation
(Smetacek 1985, Logan \& Alldredge 1989). In some areas of the ocean, e.g. areas with upwelling, as well as in certain circumstances when aggregates do not sink (Rinaldi et al. 1995), an increase in the survival time of diatoms by 10 to $20 \mathrm{~d}$ will appreciably increase the probability of the diatoms to again find themselves in growth-favoring conditions. Aggregation appears less advantageous, at least for the surface ecosystem, under different circumstances. According to our results and assuming a sinking velocity for aggregates of $100 \mathrm{~m} \mathrm{~d}^{-1}$ (Alldredge \& Gotschalk 1988, Alldredge \& Silver 1988), diatom aggregates would reach a depth of $>1400$ to $1700 \mathrm{~m}$ before dissolution rates of aggregated diatoms would increase to values similar to those of freely suspended cells. The dSi released at this depth then needs to be transported back to the euphotic zone before it can support renewed diatom growth. In this case, aggregation will not favor sustained diatom production in surface waters. Of course, these aggregates will play another ecological role for flux feeders inhabiting the mesopelagic layer (Jackson 1993), and one might suspect that the activity of such organisms will redistribute the depth of $\mathrm{bSiO}_{2}$ dissolution over a wide range.

Acknowledgements. We are grateful to everyone in the Cgroup of the AWI for their support during experiments. Thanks to A. Engel for her contributions in the initial stages of our research, and to M. Ernst and S. Säuberlich for their help with bacteria enumeration, to A. Terbrüggen, M. Wolff, G. Langer, M. Briand, and R. Marc for their technical assistance. Thanks to S. ni Longphuirt and Christina De La Rocha, who kindly read earlier versions, and to J. Grall for his help with statistics. This work was funded by the EU, partly through the ORFOIS (EVK2-CT2001-00100) project and partly through the Si-WEBS (HPRN-CT-2002-00218) Research Training network of the Marie Curie program. This is Contribution No. 1025 of the IUEM and 16142 of the AWI.

\section{LITERATURE CITED}

Alldredge AL, Gotschalk C (1988) In situ settling behaviour of marine snow. Limnol Oceanogr 33:339-351

Alldredge AL, Silver MW (1988) Characteristics, dynamics and significance of marine snow. Prog Oceanogr 20:41-82

Alldredge AL, Youngbluth MJ (1985) The significance of macroscopic aggregates (marine snow) as sites of heterotrophic bacterial production in the mesopelagic zone of the subtropical Atlantic. Deep-Sea Res 32:1445-1456

Alldredge AL, Cole J, Caron DA (1986) Production of heterotrophic bacteria inhabiting organic aggregates (marine snow) from surface waters. Limnol Oceanogr 3:68-78

Alldredge AL, Passow U, Haddock HD (1998) The characteristics and transparent exopolymer particle (TEP) content of marine snow formed from thecate dinoflagellates. J Plankton Res 20:393-406

Bidle KD, Azam F (1999) Accelerated dissolution of diatom silica by marine bacterial assemblages. Nature 397:508-512

Bidle KD, Azam F (2001) Bacterial control of silicon regeneration from diatom detritus: significance of bacterial ecto- 
hydrolases and species identity. Limnol Oceanogr 46: 1606-1623

Bidle KD, Manganelli M, Azam F (2002) Regulation of oceanic silicon and carbon preservation by temperature control on bacteria. Science 298:1980-1984

Blank GS, Sullivan CW (1979) Diatom mineralization of silicic acid-III, $\mathrm{Si}(\mathrm{OH})_{4}$ binding and light dependent transport in Nitzschia angularis. Arch Microbiol 123:157-164

Brzezinski MA, Alldredge AL, O'Bryan LM (1997) Silica cycling within marine snow. Limnol Oceanogr 42:1706-1713

Cushing DH (1989) A difference in structure between ecosystems in strongly stratified waters and in those that are only weakly stratified. J Plankton Res 11:1-13

Dachs J, Bayona JM (1998) On the occurrence of microscale chemical patches in fractal aggregates. Ecol Model 107:87-92

Dugdale RC, Wilkerson FP, Minas HJ (1995) The role of a silicate pump in driving new production. Deep-Sea Res I 42:697-719

Goldmann JC (1993) Potential role of large oceanic diatoms in new primary production. Deep-Sea Res I 40:159-168

Gordon LI, Jennings JC, Ross AA, Krest JM (1993) A suggested protocol for continuous flow automated analysis of seawater nutrients in the WOCE hydrography program and the JGOFS study. Tech Rep No. 93-1, OSU College of Oceanography, Corvallis, OR

Gotschalk C, Alldredge AL (1989) Enhanced primary production and nutrient regeneration within aggregated marine diatoms. Mar Biol 103:119-129

Graf G (1992) Benthic-pelagic coupling: a benthic view. Oceanogr Mar Biol Annu Rev 30:149-190

Greenwood J, Truesdale VW, Rendell AR (2001) Biogenic silica dissolution in seawater-in vitro chemical kinetics. Prog Oceanogr 48:1-23

Grossart HP, Simon M (1993) Limnetic macroscopic organic aggregates (lake snow): occurrence, characteristics, and microbial dynamics in Lake Constance. Limnol Oceanogr 38:532-546

Guillard RRL (1975) Culture of phytoplankton for feeding marine invertebrates. Plenum Press, New York

Guillard RRL, Ryther JH (1962) Studies of marine planktonic diatoms. I. Cyclotella nana Hustedt and Detonula confervacae (Cleve). Gran Can J Microbiol 8:229-239

Hannides AK, Shannon MD, Aller RC (2005) Diffusion of organic and inorganic solutes through macrofaunal mucus secretions and tube linings in marine sediments. J Mar Res 63:957-981

Jackson GA (1993) Flux feeding as a mechanism for zooplankton grazing and its implications for vertical particulate flux. Limnol Oceanogr 38:1328-1331

Kamatani A (1982) Dissolution rates of silica from diatoms decomposing at various temperatures. Mar Biol 68:91-96

Kamatani A, Riley JP (1979) Rate dissolution of diatom silica walls in seawater. Mar Biol 55:29-35

Logan BE, Alldredge AL (1989) Potential for increase nutrient uptake by flocculating diatoms. Mar Biol 101:443-450

Mullin JB, Riley JP (1965) The spectrophotometric determination of silicate-silicon in natural waters with special reference to seawater. Anal Chim Acta 46:491-501

Nelson DM, Goering JJ, Kilham SS, Guillard RRL (1976) Kinetics of silicic acid uptake and rates of silica dissolution in the marine diatom Thalassiosira pseudonana. J Phycol $12: 246-252$

Nelson DM, Ahern JA, Herlihy LJ (1991) Cycling of biogenic silica within the upper water column of the Ross Sea. Mar Chem 35:461-476

Nelson DM, Tréguer P, Brzezinski MA, Leynaert A, Quéguiner B (1995) Production and dissolution of biogenic silica in the ocean: revised global estimates, comparison with regional data and relationship to biogenic sedimentation. Global Biogeochem Cycles 9:359-372

Passow U (2000) Formation of transparent exopolymer particles, TEP, from dissolved precursor material. Mar Ecol Prog Ser 192:1-11

Passow U (2002a) Transparent exopolymer particles (TEP) in aquatic environments. Prog Oceanogr 55:287-333

Passow U (2002b) Production of TEP by phytoplankton and bacteria. Mar Ecol Prog Ser 236:1-12

Passow U, Alldredge AL (1994) Distribution, size and bacterial colonization of transparent exopolymer particles (TEP) in the ocean. Mar Ecol Prog Ser 113:185-198

Passow U, Alldredge AL (1995a) Aggregation of a diatom bloom in a mesocosm: the role of transparent exopolymer particles (TEP). Deep-Sea Res II 42:99-109

Passow U, Alldredge AL (1995b) A dye-binding assay for spectrophotometric measurement of transparent exopolymer particles. Limnol Oceanogr 40:1326-1335

Passow U, Alldredge AL, Logan BE (1994) The role of particulate carbohydrate exudates in the flocculation of diatom blooms. Deep-Sea Res I 41:335-357

Passow U, Engel A, Ploug H (2003) The role of aggregation for the dissolution of diatom frustules. FEMS Microbiol Ecol 46:247-255

Patrick S, Holding AJ (1985) The effect of bacteria on the solubilization of silica in diatom frustules. J Appl Bacteriol 59:7-16

Ploug H, Passow U (2007) Direct measurement of diffusivity within diatom aggregates containing transparent exopolymer particles. Limnol Oceanogr 52:1-6

Ragueneau O, Tréguer P (1994) Determination of biogenic silica in coastal waters: applicability and limits of the alkaline digestion method. Mar Chem 45:43-51

Ragueneau O, Tréguer P, Leynaert A, Anderson RF and 11 others (2000) A review of the Si cycle in the modern ocean: recent progress and missing gaps in the application of biogenic opal as a paleoproductivity proxy. Global Planet Change 26:317-365

Ragueneau O, Gallinari M, Corrin L, Grandel S and 7 others (2001) The benthic silica cycle in the Northeast Atlantic: annual mass balance, seasonality, and importance of non steady state processes for the early diagenesis of biogenic opal in deep-sea sediments. Prog Oceanogr 50:171-200

Ragueneau O, Dittert N, Pondaven $\mathrm{P}$, Tréguer $\mathrm{P}$, Corrin L (2002) Si/C decoupling in the world ocean: Is the Southern Ocean different? Deep-Sea Res II 49:3127-3154

Rinaldi A, Vollenweider RA, Montanari G, Ferrari CR, Ghetti A (1995) Mucilages in Italian seas: the Adriatic and Thyrrhenian Seas, 1988-1991. Sci Total Environ 165: 165-183

Shanks AL, Edmondson EW (1989) Laboratory-made artificial marine snow: a biological model of the real thing. Mar Biol 101:463-470

Shanks AL, Trent JD (1980) Marine snow: sinking rates and potential role in marine flux. Deep-Sea Res I 27:137-144

Silver MW, Alldredge AL (1981) Bathypelagic marine snow: deep-sea algae and detrital community. J Mar Res 39: 501-530

Silver MW, Shanks AL, Trent JD (1978) Marine snow: microplankton habitat and source of small-scale patchiness in pelagic populations. Science 201:341-371

Smetacek V (1985) Role of sinking in diatom life history cycles: ecological, evolutionary and geological significance. Mar Biol 84:239-251

Smith CR, Hoover DJ, Doan SE, Pope RH, Demaster DJ, Dobbs FC, Altabet MA (1996) Phytodetritus at the abyssal 
seafloor across $10^{\circ}$ of latitude in the central equatorial Pacific. Deep-Sea Res II 43:1309-1338

Smith DC, Simon M, Alldredge AL, Azam F (1992) Intense hydrolytic enzyme activity on marine aggregates and implications for rapid particle dissolution. Nature 359: 139-141

Thornton DCO (2002) Diatom aggregation in the sea: mechanisms and ecological implications. Eur J Phycol 37:149-161

Tréguer P, Le Corre P (1975) Manuel d'analyse des sels nutritifs dans l'eau de mer: utilisation de l'auto-analyseur Technicon II. Université de Bretagne Occidentale, Brest

Turner JT (2002) Zooplankton faecal pellets, marine snow and sinking phytoplankton blooms. Aquat Microb Ecol 27: 57-102

Utermöhl H (1958) Zur Vervollkommnung der quantitativen Phytoplanktonmethodik. Mitt Int Ver Theor Angew Limnol 9:1-38

Van Cappellen P, Qiu L (1997a) Biogenic silica dissolution in sediments of the Southern Ocean. I. Solubility. Deep-Sea Res II 44:1109-1128

Editorial responsibility: Otto Kinne (Editor-in-Chief), Oldendorf/Luhe, Germany
Van Cappellen P, Qui L (1997b) Biogenic silica dissolution in sediments of the Southern Ocean. II. Kinetics. Deep-Sea Res II 44:1129-1149

Van Cappellen P, Dixit S, Van Beusekom J (2002) Biogenic silica dissolution in the oceans: reconciling experimental and field-based dissolution rates. Global Biogeochem Cycles 16:1075. DOI: 1010.1029/2001GB001431

Velji MI, Albright LJ (1993) Improved sample preparation for enumeration of aggregated aquatic substrate bacteria. Lewis Publishers, Boca Raton, FL

Wassmann P, Hansen L, Andreassen IJ, Riser CW, UrbanRich J (1999) Distribution and sedimentation of faecal pellets on the Nordvestbanken shelf, northern Norway, in 1994. Sarsia 84:239-252

Welch SA, Ullman WJ (1993) The effect of organic acids on plagiocase dissolution rates and stoichiometry. Geochim Cosmochim Acta 57:2725-2736

Welch SA, Vandevivere P (1994) Effect of microbial and other naturally occurring polymers on mineral dissolution. Geomicrobiol J 32:227-238

Submitted: October 28, 2004; Accepted: July 10, 2006

Proofs received from author(s): February 23, 2007 